\title{
PENGELUARAN HORMON ENDORPHINE ALAMI DENGAN METODE TRANSCUTANEOUS ELECTRICAL NERVE STIMULATION (TENS) UNTUK MENGENDALIKANINTENSITAS AFTERPAIN PADA IBU NIFAS
}

\author{
1)Waifti Amalia, ${ }^{2)}$ Nicky Danur Jayanti, ${ }^{3)}$ Novita Mayasari \\ Program Studi D3 Kebidanan STIKES Widyagama Husada \\ ${ }^{1)}$ pickupmyaccount@yahoo.co.id \\ 2)nicky_daanty@yahoo.co.id
}

\begin{abstract}
Afterpain is a feeling of heartburn due to the periodic contraction and relaxation of the uterus that causes pain during the beginning of puerperium. Pain or a feeling of heartburn is a serious problem and if it is ignored, it will be bad for the health of mother and baby. In addition to drugs, afterpain can be mitigated by using a tool that does not cause side effects. The purpose of this study was to find out the influence of the natural endorphin hormone release using the Transcutaneous Electrical Nerve Stimulation (TENS) to Control the intensity of afterpain on postpartum women. This study applied a one-group pretest-posttest design. The population were 20 puerperal women. Based on the data collected, after 15-minute treatment of the TENS method, it was found that the intensity of afterpain in 18 puerperal women (90\%) changed from the level of moderate pain to mild pain. In addition, there were two puerperal women (10\%) who experienced worst pain who finally felt moderate pain after the treatment. The data were analyzed using the Wilcoxon Signed Rank Test and resulting the value of $Z=-4.472$ and $A$ symp Sig (2-tailed) $=0.000$. When compared with $\alpha=0.05$, then A syimp Sig (2-tailed) $<\alpha$, so $H o$ was rejected. It meant that there was significant implementation method of Transcutaneous Electrical Nerve Stimulation (TENS) to decrease the intensity of afterpain in puerperal women.
\end{abstract}

Keyword: Transcutaneous Electrical Nerve Stimulation (TENS), Pain, Afterpain 


\section{Abstrak}

Afterpain adalah perasaan mulas akibat relaksasi dan kontraksi yang periodik dari uterus dan menimbulkan nyeri yang bertahan sepanjang masa awal puerperium. Nyeri atau perasaan mulas ini merupakan masalah yang serius dan jika diabaikan akan berdampak buruk bagi kesehatan ibu dan bayinya. Selain dengan obat-obatan, afterpain dapat diredakan dengan menggunakan alat yang tidak menimbulkan efek samping. Tujuan dari penelitian ini adalah untuk mengetahui pengaruh Pengeluaran Hormon Endorphine Alami Dengan Metode Transcutaneous Electrical Nerve Stimulation (TENS) Untuk Mengendalikan Intensitas Afterpain pada ibu nifas. Penelitian ini menggunakan one group pre test-post test desain dengan populasi sebanyak 20 orang ibu nifas. Setelah dilakukan perlakuan selama 15 menit dengan menggunakan metode TENS, intensitas afterpain pada ibu nifas dievaluasi. Dari hasil penelitian didapatkan data bahwa sebanyak 18 orang (90\%) ibu nifas mengalami nyeri sedang dan $2(10 \%)$ ibu nifas mengalami nyeri berat sebelum diberikan metode TENS. Setelah diberikan metode TENS sebanyak 18 (90\%) ibu nifas mengalami penurunan nyeri menjadi nyeri ringan dan 2 orang (10 \%) ibu nifas mengalami penurunan nyeri menjadi nyeri sedang. Hasil analisa data menggunakan Wilcoxon Signed Rank Test. Dari hasil analisa didapatkan nilai $Z=-4,472$ dan nilai A syimp Sig (2-tailed) $=0,000$. Jika dibandingkan dengan $\alpha=0,05$ maka A syimp Sig (2-tailed) $<\alpha$, dengan demikian maka Ho ditolak yang artinya terdapat pengaruh implementasi metode Transcutaneous Electrical Nerve Stimulation (TENS) terhadap intensitas afterpain pada ibu nifas.

Keyword: Nyeri, Pasca Melahirkan, Transcutaneous Electrical Nerve Stimulation (TENS)

\section{PENDAHULUAN}

Nifas adalah masa yang dimulai setelah plasenta lahir dan berakhir ketika alat-alat kandungan kembali seperti keadaan sebelum hamil, berlangsung selama kira-kira 6 minggu (Prawirorahardjo, 2002). Proses perubahan fisik tersebut terkadang menimbulkan rasa tidak nyaman yang dikenal sebagai nyeri pasca melahirkan (afterpain).

Afterpain atau mules-mules sesudah partus merupakan akibat dari kontraksi uterus yang terkadang sangat mengganggu, biasanya berlangsung 2 3 hari postpartum . Selama dua jam pertama setelah melahirkan, kontraksi uterus menjadi teratur dan kuat, khususnya pada wanita multipara. Kekuatan kontraksi miometrium yang terjadi cukup kuat, tekanan intrauterine jauh lebih besar dibanding sewaktu persalinan, dapat mencapai $150 \mathrm{mmHg}$ atau lebih dan terasa lebih berat saat menyusui pasca melahirkan.

Nyeri atau perasaan mules setelah melahirkan merupakan masalah yang utama yang perlu mendapatkan perhatian khusus dan serius. Keadaan tersebut akan berdampak buruk bagi kesehatan ibu dan bayinya. Ibu akan mengalami gangguan proses fisiologis setelah melahirkan dan hal ini berdampak terhadap kesehatan bayinya. Kondisi seperti ini memicu ibu untuk tidak memberikan ASI dan beralih pada pemberian PASI (Nursalam, 2009).

$$
\text { Upaya yang dapat dilakukan }
$$
untuk mengatasi ketidaknyamanan afterpain tersebut diantaranya dengan metode farmakologi seperti pemberian analgesik, dan metode non farmakologi seperti massage, kompres hangat, gerakan, akrupresur, akupunktur, teknik distraksi dan relaksasi, dan 
TENS (Trancutaneus Electrical Nerve Stimulation). Transcutaneous Electrical Nerve Stimulation (TENS) merupakan suatu cara penggunaan energi listrik untuk merangsang sistem saraf melalui permukaan kulit (Johnson M, 2002).

TENS merupakan salah satu terapi non farmakologi yang telah menunjukkan hasil yang efektif dalam menanggulangi nyeri pada berbagai kondisi. TENS diterima sebagai metode pengontrol nyeri yang non invasive dan non narkotik (Dawood MY, 1990). TENS mampu mengaktivasi baik serabut berdiameter besar maupun berdiameter kecil yang akan menyampaikan berbagai informasi sensorif ke sistem saraf pusat. Efektivitas TENS dapat diterangkan melalui teori gerbang control (GateControl).

Looser JD, et al, (1999) TENS tipe konvensional memberikan stiumulasi dengan frekuensi tinggi, amplitudo rendah (0-100 MA) dengan durasi sampai 200 mikro detik dengan waktu 30 menit dapat mengurangi nyeri dalam waktu 10-15 menit. Tipe konvensional dapat digunakan untuk berbagai nyeri muskuloskeletal dan menimbulkan perasaan nyaman.

Berdasarkan fenomena tersebut, permasalahannya adalah bagaimana pengeluaran hormone endorphine alami dengan metodeTranscutaneous Electrical Nerve Stimulation (TENS) untuk mengendalikan intensitas afterpain pada ibu nifas.

\section{METODE PENELITIAN}

Berikut adalah langkah-langkah yang dilakukan pada penelitian ini:

1. Data yang diambil langsung dari ibu nifas di BPM Dillah Sobirin untuk dijadikan responden dalam penelitian ini dan pengumpulan data dilakukan dengan menggunakan wawancara dan lembar observasi yang berisi alat ukur nyeri.

2. Pengukuran nyeri yang dilakukan ketika ibu memasuki kala IV.

3. Setelah diukur nyerinya, memasang 2 elektroda yaitu elektroda positif dan elektroda negatif pada daerah pinggang setingkat thorakal $10 \mathrm{ke}$ masing - masing responden, setelah itu diatur kekuatan intensitas TENS sesuai dengan kenyamanan responden dan dilakukan selama 15 menit.

4. Menanyakan kembali tingkat nyeri yang dirasakan ibu setelah diberi metode TENS.

5. Pada saat pemberian metode TENS ibu tidak sedang ditemani oleh keluarga ataupun suaminya, sedangkan peneliti juga tidak memberikan intervensi apapun kepada ibu.

6. Sebelumnya peneliti juga memberikan penjelasan dimana responden bisa memilih atau menunjukkan skor nyeri dengan ketentuan ujung yang paling kiri tidak terdapat rasa nyeri dan ujung yang paling kanan nyeri hebat.

7. Lembar observasi ini diberikan kepada responden dan di check oleh peneliti dengan syarat sebelumnya responden menandatangani inform consent.

\section{Teknik Pengolahan Data}

Data yang sudah terkumpul selanjutnya akan dilah dalam beberapa tahapan, yang meliputi: editing, coding, scoring, transfering, tabulating, dan 
selanjutnya dianalisis statistik dengan program software SPSS 16.

\section{HASIL YANG DICAPAI}

Hasil yang dicapai pada penelitian ini adalah :

1. Sebelum dilakukan perlakuan dengan metode TENS, masing masing responden di wawancara untuk mengisi lembar data demografi. Selanjutnya pasien diminta untuk menunjukkan titik yang mampu menggambarkan rasa nyerinya. Dari 20 responden, terdapat 18 responden $(80 \%)$ yang mengalami nyeri sedang dan 2 responden $(10 \%)$ yang mengalami nyeri berat.

2. Meraba thorakal ke 10 dengan cara ibu menghadap ke belakang, kemudian ditarik garis antara 2 tulang skapula selanjutnya ditambah 5 tulang ke bawah. Selanjutnya membersihkan area yang akan di beri perlakuan dengan kassa steril, selanjutnya menempelkan elektroda selama 15 menit dengan frekuensi yang dikehendaki pasien.

3. Mengukur kembali tingkat nyeri setelah diberikan perlakuan dengan metode TENS. Dari 20 responden, 18 responden (90\%) mengalami nyeri ringan dan 2 responden (10\%) mengalami nyeri sedang.

4. Pengujian dengan teknik analisa data menggunakan Wilcoxon Signed Rank Test. Dari hasil analisa didapatkan nilai $Z=-4,472$ dan nilai A syimp Sig (2-tailed) $=0,000$. Jika dibandingkan dengan $\alpha=0,05$ maka A syimp Sig (2-tailed) $<\alpha$, dengan demikian maka Ho ditolak yang artinya terdapat pengaruh implementasi

metode

Transcutaneous Electrical Nerve

Stimulation (TENS) terhadap intensitas afterpain pada ibu nifas.

Dari hasil penelitian yang telah dilaksanakan pada 20 responden, didapatkan data bahwa terdapat $90 \%$ atau 18 responden mengalami nyeri sedang dan 2 responden atau 10\% mengalami nyeri berat. Sedangkan sesudah pemberian metode TENS sebanyak $90 \%$ atau 18 responden mengalami nyeri ringan dan $10 \%$ atau 2 responden mengalami nyeri sedang. Nyeri yang dirasakan merupakan sensasi yang timbul karena adanya trauma pada jaringan tubuh akibat iskemi otot - otot uterus karena pengaruh hormonal dan beban sehingga menimbulkan kontraksi. Hal inilah yang merangsang reseptor nyeri secara kimiawi untuk mengeluarkan bradikinin, serotonin, histamin, ion $\mathrm{K}$, asam asetilkolin dan asam proteolitik.

Selain itu prostaglandin dan substansi $\mathrm{P}$ meningkatkan sensitivitas ujung-ujung serabut nyeri sehingga dapat menimbulkan rasa nyeri.

Proses transmisi nyeri terjadi karena adanya impuls-impuls nyeri disalurkan ke sumsum tulang belakang oleh serabut saraf bermielin (serabut Adelta) yang jelas melokalisasi sumber nyeri, mendeteksi intensitas nyeri dan menghantarkan komponen suatu cedera akut dengan segera. Transmisi stimulus nyeri tersebut berlanjut di sepanjang serabut saraf aferen sampai berakhir di bagian kornu dorsalis medula spinalis. Neurotransmiter dalam kornu dorsalis melepaskan substansi $\mathrm{P}$ sehingga menyebabkan suatu transmisi sinapsis dari saraf 
perifer (sensori) ke saraf traktus spinotalamus yang menyeberangi sisi yang berlawanan dengan medula spinalis. Impuls nyeri kemudian naik ke medula spinalis, maka informasi ditransmisikan dengan cepat ke pusat yang lebih tinggi di otak untuk mempersepsikan sensasi nyeri (Potter, 2005: 1504-1505).

\section{KESIMPULAN}

Kesimpulan dari hasil penelitian saat ini adalah dengan menggunakan metode TENS pasien menjadi lebih tenang dalam menghadapi nyeri afterpain. Sedangkan dari hasil wawancara yang didapatkan, responden menyatakan bahwa nyeri yang dirasakannya sudah banyak berkurang.

\section{DAFTAR PUSTAKA}

Alimul H, Aziz. 2003. Riset Keperawatan Dan Teknik Penulisan Ilmiah. Jakarta: Salemba Medika.

Anonim. 2007. Transcutaneous Electrical Nerve Stimulation. http://millercenter.uchicago.edu/lea rnaboutpnltreatment/te ns.shtml.

Arikunto, Suharsimi. 2006. Prosedur Penelitian sebuah Pendekatan Praktik. Jakarta: Rineka Cipta.

Bobak,dkk. 2004. Buku Ajar Keperawatan Maternitas Edisi 4. Jakarta: EGC.

Brunner \& Suddart. 2001. Keperawatan Medikal Bedah edisi 8 Vol I. Jakarta: EGC.

Corazza, M, maranini, C, Bacilieri, S, Virgili, A. 1991. Accelerated allergic contact dermatitis to a transcutaneous electrical nerve stimulation device. Dermatology 199:281.
Danuatmaja, Bonny. 2003. 40 Hari Pasca Persalinan Masalah dan Solusinya. Jakarta: Puspa Sehat.

Davis.2007. Transcutaneous Electrical Nerve Stimulation. http://www.midwifeinfo.comlarticl es/tens-transcutaneous-electricalnerve-stimulations.

Fajar, Ibnu, et.al. 2009. Statistika untuk Praktisi Kesehatan. Yogyakarta: Graha Ilmu.

Forums, Bluefame. 2009. Pasca Persalinan. http://konsultasikesehatan.epajak.o rg.

Huliana, Mellyna.2003. Perawatan Ibu Pasca Melahirkan. Jakarta: Puspa Sehat.

ISO. 2008. Informasi Spesialite Obat Indonesia. Jakarta: Ikatan Sarjana Farmasi Indonesia.

Johnson, MI. 2001. The Analgesic Effects and Clinical Use of Acupunture like TENS(Al Tens). Phisical Therapy Reviews 3.

Kane, K Taub, A. 1975. A History of Local Electrical Analgesia. Pain 1 : 125-138.

Ladewig, Patricia. 2006. Asuhan Keperawatan Ibu-bayi Lahir. Jakarta: EGC.

Lestari, Ana Dwi. 2009. Asuhan cKeperawatan Klien Dengan Nifas. http://ana.wordpress.com/2009/10,a suhan-keperawatan-klien-dengannifas/,2010)

Melzack,R, Wall,P. 1965. Pain Mechanism: A new theory. Science 150:971-979.

Mochtar, Rustam. 1998. Sinopsis Obstetri. Jakata: EGC. 
Nolan, Mary. 2004. Kehamilan $\mathcal{E}$ Melahirkan. Jakarta: Arcan.

Notoadmodjo, S. 2005. Metodologi Penelitian Kesehatan. Jakarta: Rineka Cipta.

Nursalam. 2008. Konsep dan Penerapan metodologi Penelitian Ilmu Keperawatan. Jakarta: Salemba Medika.

Potter dan Perry. 2005. Buku Ajar Fundamental Keperawatan.Vol 2, Edisi 4. Jakarta: EGC.

Prawirohardjo, Sarwono. 2002. Ilmu Kebidanan. Jakarta: Bina Pustaka

Reska. 2009. Hubungan Pengetahuan dengan Sikap Suami Tentang Seksualitas Setelah Ibu melahirkan Di Polindes Sejahtera Jatiguwi-Malang. Poltekkes Depkes: Malang.

Retnowati, Ayu. 2009. Efektivitas Transcutaneous Electrical Nerve Stimulation (TENS) Terhadap Penurunan Dismenorrea Pada Mahasiswa di Asrama Prodi Kebidanan Malang.Malang:Karya Tulis Ilmiah.

Rianto, Slamet. 2000. Terapi-Terapi Alternatif. Yogyakarta: Lotus.

Robinson.et.al. 2008. Transcutaneous Electrical Nerve Stimulation. http://en.wikipedia.org/wiki/Transc utaneous_electrical_nerve_stimulat ion.

Steven, P.J.M., Bordui, F., Almekinders, G.I., Meer, V.w.e. 1999. Ilmu Keperawatan, Jilid I Edisi II, Jakarta: EGC.

Steven. 2007. Transcutaneous Electrical Nerve stimulation. http://74.125.153.132/search?q=cach
e:CvGdroVZZ4gJ:emedicine.medsc ape.com/

Sugiyono. 2006. Statistika Untuk Penelitian. Bandung: Alfabeta.

Yuliatun, Laily. 2008. Penanganan Nyeri Persalinan Dengan Metode Non Farmakologi. Malang : Bayumedia. 